\title{
On the Experience of Motivating Technical University Students to Communicate in a Foreign Language
}

Ekaterina N. Karakozova, Yulia S. Perevezentseva and Dmitry V. Lastochkin* Nizhny Novgorod State Technical University named after R.E. Alekseev 24 Minin Str., Nizhny Novgorod, 603950, Russia

Received 22.05.2017, received in revised form 09.01.2017, accepted 16.01.2018

The present paper describes the experiment aimed at developing motivation of foreign language communication among technical university students. This research was made in three phases. The first one was to diagnose the state of students' motivation according to the test by A. Mehrabian. The second stage was a forming experiment, carried out on the basis of programs named "Formation of communicating motivation in the process of studying foreign language in higher school". These programs included certain tasks and exercises aimed at developing some communication skills of students (making contact, developing self-confidence and self-awareness). The third stage was the final diagnosis, which is a re-test to determine the level of communicating needs among students. The results obtained thanks to careful analysis of communicating motivation dynamics can be used to control further development of students' personal qualities.

Keywords: communication skills, motivation, communication, affiliation, personal qualities of a student.

DOI: $10.17516 / 1997-1370-0207$.

Research area: pedagogy, psychology.

\section{Introduction}

Over all his life of a human tries to use to all the previous experience of the society, existing in the form of skills and abilities. This process is determined by two features: 1 . The human transforms the world, under the influence of already existing knowledge; 2 . The use of human experience and the satisfaction of his needs takes place in the process of communication.
A huge amount of works is devoted to the description of practices and techniques of communication. Among other relevant topics, one of those under discussion is the question of the origins of communication. First, it is still not clear whether the communication need is something unique, quite different from other needs (social or spiritual) or it is just assumed to be a form of those. Second, if a need to communicate really

C) Siberian Federal University. All rights reserved

* Corresponding author E-mail address: khokhlovaj@mail.ru 
exists, what is its origin: whether it is congenital (basic) or secondary, i.e, is formed in ontogenesis in the process of socialization of the child.

In our opinion, the problem of occurrence of communication can not be solved completely without studies of such aspect of it as motivation. The term, proceeding from results of works of a number of researchers, is defined in different ways (Larina, 2011; Sukhanova, 2010; Mitina, 2004). But, according to A.G. Asriyan, all of them, actually, can be reduced to two: the first - motivation as a set of factors and motives; the second - motivation as dynamic education as a mechanism, as a process (Asrian, 2009: 353-354). Taking the first definition as the correct one, it is possible to say that in the course of taking over the world a person has all new requirements, desires and, consequently- motives. It is important to note that communication in different periods of human life develops differently. In the process of taking over the world there are new needs, desires and thus motives. The latter, according to V.N. Kunitsyna and N.V. Kazarinova, "may be mutually exclusive and mutually reinforcing - from selfish to altruisticmanipulative-disinterested. Tying to make relationships, people strive to lead, dominate, impress, maintain the image of a friendly and easy-going person, etc". (Kunitsyna, Kazarinova, 2001: 29). N.P. Erastov believes that communication motives may be caused not only by a specific need, but also by some interest, habit, caprice or debt (Erastov, 1979: 74). Some foreign psychologists explain the desire to communicate by affiliation by desire to "make friends and feel affection. To feel joy meeting other people and to live with them. Cooperate and communicate with them. To love. To join the group" (Hekhauzen, 2003: 289) - in other words, by human need for emotional and trust communication.

\section{Problem statement}

For us, the problem of motivation in communication is interesting not as itself, but as a part of university training activities. Our focus is on foreign language classes, during which the communicative activity, according to FGOS (Russian Federal State Educational Standard) is decisive. In order to activate or cause interest to study the language, teachers often use methods of interaction, as well as multimedia and role-playing games. However, according to our teaching experience, only some students who are more or less aware and confident in their knowledge try to interact. In our opinion, motivation, while studying a foreign language is of very high importance, as even excellent language skills can be lost without a want to use them. The target of our research is how to increase a need to communicate in a foreign language (particularly, in English), by using some psychological methods, rather than just explaining the importance of the English language in the modern world.

\section{Discussion}

\section{Primary test research}

A target audience of our experiment was bachelor students of Nizhny Novgorod State Technical University named after R.E. Alekseev (specialities of Nuclear Physics and Reactors, and Information Technologies). This choice was determined by the following reasons: first, the desire of the students to take part in the experiment, and second - we had an access to these groups, as we were their teachers. Third, the experimental group was chosen so that its participants were those students whose level of English hadn't changed by the end of the first year of studying (according to the test which included reading, listening, speaking and writing and remained pre-intermediate A-2). It should be noted, that attendance of those students was 
Table 1. Results of primary psychological diagnosis according to A. Mehrabian test

\begin{tabular}{|c|c|c|}
\hline Level & Number of people & Percentage (\%) \\
\hline "High-low" & 13 & 37 \\
\hline "Low-low" & 4 & 11 \\
\hline "High-high" & 9 & 26 \\
\hline "Low-high" & 9 & 26 \\
\hline
\end{tabular}

quite regular. Moreover, most of the enterprises where graduates start to work want the level of English knowledge not less than B1. Thus, the idea of "not importance" of the foreign language for the students of the experimental group was thrown away. Trying to determine other reasons of stagnation in studying foreign language, we found it necessary to evaluate the level of need in communication (affiliation) among the participants of the experimental group. To do this, we made the diagnostics of affiliation motives, according to A. Mehrabian. Students, tested, according to this methodology, were given a few dozens of statements, with which they had to either agree or disagree, following three-point scale. Two motivation tendencies were evaluated: commitment to people and the fear of being rejected. The participants of the experiment were given two questionnaires, one of them was to evaluate the first motivating tendency, and the other - the second. The following typical combinations of the motives discussed and ways of their interpreting were possible (Table 1):

1. High level of development of "commitment to people", motive combined with a high level of development of motive "fear of being rejected". The individual is characterized by a pronounced internal conflict between the commitment to the people and avoiding them, which occurs every time when he has to meet with strangers.

\section{High level of development of "commitment} to people" motive combined with a low level of development of "fear of being rejected" motive. Such a person actively looks for contacts and communication with people and experiences mostly positive emotions from this.

\section{High level of development of motive "fear} of being rejected" in conjunction with the low level of development of "commitment to people" motive. The individual actively avoids contact with people and looks for solitude.

4. Low level of development of both motives.

This combination of motivational trends data describes a man who, living among the people, communicating with them, does not feel either positive or negative emotions and feels good, both among people and without them.

So, only $37 \%$ of participants have mostly positive emotions from contact with other people. $26 \%$ of students fell fear of people. $11 \%$ have neither positive nor negative emotions while communicating. $37 \%$ of students have a low need for communication.

So, our target was to increase the motivation to communicate among the tested.

\section{Forming experiment}

From January to April 2015 the students of the experimental group were given weekly English lessons in the framework of the program "Formation of communicating motivation in the process of studying foreign language in higher school".

Before the start of classes the students had read an introductory lecture on the problems of motivation of communication in interpersonal relationships. After that, the system exercises began. The implementation of our program, 
"Formation of motivation to communicate in foreign language classes at the university", which was provided by the teachers of the Chair of Foreign languages, Nizhniy Novgorod Technical University. The program consisted of 3 stages:

I. Formation of establishing contact skills. Students learn to create and maintain a sense of mutual interest. This sense includes: 1 . The subject of interest to other people; 2 . The interest of other people to the subject.

II. The development of self-confidence. Students learn to create and maintain satisfactory relationships with people, based on control and power.

At the same time, they try to create and maintain, the sense of mutual respect, based on competence and responsibility.

III. Formation of self-consciousness. Be a human, not like the others, i.e., be an individual, to be noticed - the main goal of phase. At each stage the participants of the experimental group were offered certain tasks based on some clear, simplified lexics (as their level was A2). Let us consider some of these tasks.

Examples of exercises that were carried out on the first stage of the "Formation of skills to establish contact":

1.1. The purpose of the exercise - to learn to be aware of the emotional response to the external manifestations of personality, including the voice.

Pay attention to someone's voice. How does it sound? Monotone? Variable? At high tones? Sharp? Squeaky? Melodiously? Too quiet/loud? What articulation, is it easy to understand what is told? Is the speech free or it has pauses, hesitation, stop?

Now ask yourself two questions. First, what is your emotional response to certain qualities of voice; Are you annoyed because, for example, it is too low, or confusing due to the fact that it is too loud. Second: What, in your opinion, the emotional state of the speaker is, what is behind each of the seen voice qualities? Aching? Obsequious? Sexual? Angry? Does the tone correspond to what is said? Is not the speaker trying to cause the same reaction as his voice?

1.2. "Verbalization". The goal is to explore the voice in different modulations as a means of real self-image.

Read the verse in English, and listen to yourself, read as you can, until you will be able to perceive integration of speech and listening. Then read the same poem using your inner speech, "in the mind". Listen to your inner voice, "pronouncing" the readable.

First, it will slow down reading and, perhaps, cause anxiety, but after a while you will be able to "listen" as fast as reading; this practice can improve your memory due to increased contact with the material.

Finally, try to "listen" to your inner "speech thinking". You will hear the incoherent, "crazy" sentences, drifting over and over again. If this is too much trouble, talk to yourself deliberately a little: "Now I'm listening to you. I do not know what to think. I'll try to do the experiment in silence "here and now". Yes, it sounds just as if I was doing it out loud. And now I have forgotten and stopped listening ..."

Mark your inner voice modulation. What is it - angry, complaining, whiny, pompous? Or it sounds like a child? Does it speak everything meticulously after the meaning has already been understood?

\section{3. "Antique store". The goal-to learn how} to experience emotions, being in different states, and share these emotions with others.

Sit in a chair, close your eyes, relax. Imagine that you are in the store, which sells antiques. Mentally select any item yourself and imagine yourself being this item. Speak on behalf of this item: how you feel; why you are in the store; who 
and where your old proprietor is and so on. Open your eyes and share your feelings with the group. Similarly, you can identify yourself with a flower, tree, animal, imagining yourself in different conditions. Do not be shy about your feelings. Try not to have uncompleted feelings.

At this stage of the work the students have learned their voices, speech, emotions, being in different situations. As the received deeper understanding of themselves they can feel more valuable and important people, and thus attract interest of other people.

Examples of exercises on the second stage of "Development of self-confidence":

2.1. "Three phrases". The goal is to increase the responsibility for words, thoughts and deeds.

Sit opposite to a partner, into his eyes, say three sentences, starting each of them with the words: "I have to". Partner is not commenting on what you have said, in turn, is to say three similar phrases. Now go back to your phrases and repeat them one by one, replacing each word, "I have to" by "I guess". Share your feelings.

Then take turns with your partner, say three sentences, each starting with the words "I can not", and then the same replacing the words "I can not" by "I do not want to". Share your experiences in connection with the change of the meaning of what you have said.

Similarly, in turn, say three sentences beginning with "I need", and then change the words to "I want to".

Finally, at the same time with your partner, say three sentences beginning with the words "I am afraid", and then change the beginning of the sentence with the words "I'd like to". The words "I have", "I can not", "I need", "I am afraid that" deny or reduce the extent of your responsibility for yourself. By changing the phrase, you increase the responsibility for your thoughts, feelings and behavior. Try to understand the feelings associated with the change in the meaning of spoken phrases. Share your experience with the group.

2.2. "Role-Playing". The goal is to eliminate the unconscious intrapersonal conflicts.

The group members take turns losing some of their intrapersonal conflicts which they have not fully understood, but which are obvious to others. For example, if a participant is not aware of it, too often apologizes, if he says something in a low voice, hesitate, then he can be asked to play the role of a shy, timid young man. At the same time he is asked to exaggerate a little bit precisely those traits that clearly expressed. If the participant is aware of his behavior and is willing to get rid of these traits, he can be asked to play the role of people with opposite traits, such as the inspector or Chief, who speaks with his subordinates only in the tone of orders and morals. For playing the role each participant is given 5-10 minutes. The rest of the time should be left for the exchange of experiences.

\section{3. "The struggle of opposites". The goal-} to realize a sense of power, and its opposite - the sense of timidity, humiliation, thus developing self-confidence, being in different states.

One of the participants is assigned the role of the attacker, another - the defender.

The attacker is to criticize a partner to scold and to teach him, speaking in a firm authoritative voice - the other person is to apologize, make excuses, to explain why he has not got anything that the attacker requires. The discussion lasts 10 minutes. Then the partners switch roles. Each participant in the dialogue should be as much as possible and be more aware of the sense of power, aggression of the attacker and a sense of timidity, humiliation, insecurity of the defender. Next, you need to compare the role played by the real behavior, discuss the experience with the group.

These exercises, which were aimed at the realization of power and strength, on the one 
hand, and timidity, weakness, on the other, allow students to go through both states, thereby enabling them to feel confident personality in all states.

\section{Exercises on the third stage of "Formation} of consciousness":

3.1. "Our face". The goal-awareness of your body emotions as a part of your individuality.

Take a comfortable position, the head should not lay on anything. Close your eyes and begin to feel your face inside, just mark what is happening to it. Gradually, after you have found any stress, strengthen it where found, even it is uncomfortable. Note if any part of the body is strained, whether some thought, image or memory comes out. Understand the basic emotion of your body. Our face always "knows what is happening".

3.2. "Life without yourself". The goal awareness of your value in the world.

Sometimes you forget about everything and at first moment it seems as if the world lives without you. Imagine now, that life goes on without you, alone. Look at the world as if from faraway the side ... Now go back to yourself. Has the world changed in your absence? Are you significant in this new situation?

How to become a living being again?

3.3. "Zones of consciousness". The goal awareness of your individuality and that of your partner by examining three areas of the world of consciousness.

Conditionally divide the world of your consciousness into three zones:

1. The outside world;

2. The inner world of your body;

3. The world of your feelings, thoughts and fantasies.

Choose a partner. Sit facing each other. Relax. Share in turn awareness of the external world (light, smell, outlook of the partner, and so on). Then switch to your world of feelings, thoughts and fantasies.

Each time we begin with the words "Now I realize that ...". Speak for 5-8 minutes, then listen carefully to your partner. In conclusion, try to "recognize" your partner. Let him do the same thing for you.

3.4. "Working with the name". The goalawareness of your identity, considering the influence of external circumstances.

One of these external circumstances is a person's name. As is known, the name or names recorded in the documents affects the fate. They reflect the expectations of parents towards the child, cultural and historical background of the story or the kind of history of the country. In addition to the official name, the man carries childhood and "special" names - those that he was called as a child's relatives and parents, those he is called today by close friends or enemies.

Participants are asked to intensify the feelings associated with the name as follows: For example, think of names and nicknames that you were called in childhood. Who gave you these names, what were the circumstances in which you were called in one way or another name? Who called? How do you feel now, when you think about these names? Do you have any nicknames now? How have you got them? What areas of your life do they affect? Do you have different names at home and work? If yes, what is the reason of it? Try to recollect the attitude to your nick different periods of your life. How is it changing? Have you been proud of your name, or have there been any periods of negative attitudes?

(For married women). How has the change or maiden name or remaining it after the marriage influenced your identity? Whose name you have and why - what does it mean for you? If your name is different from your husband's family name, how do people react to it? 
So, at this stage, the students doing some exercises in English, tried to understand and present their identity at different levels: at the level of body, mind and relationships with the outside world. They sought to understand themselves and their personality in order to be understood by other people.

\section{Final test check}

Following the experimental part, the second diagnostics of affiliation motives, according to
A. Mehrabian was made. The results were as follow (Table 2-3):

Thus, 9 participants in the experiment (26\% of the total) could increase the need for communication and make this need possible to satisfy. To reduce the fear of being rejected by the group if there is a high need for communication became possible for 5 members $(15 \%$ of the total). 2 participants (5\% of the total) who had a low need for communication and low fear of rejection could trigger emotions in the process of

Table 2. The results of the final test control

\begin{tabular}{|c|c|c|}
\hline Level & Number of people & Percentage (\%) \\
\hline "High-low" & 22 & 63 \\
\hline "Low-low" & 2 & 6 \\
\hline "High-high" & 4 & 20 \\
\hline "Low-high" & 7 & 11 \\
\hline
\end{tabular}

Table 3

\begin{tabular}{|c|c|c|c|c|c|c|c|}
\hline $\begin{array}{c}\text { number of } \\
\text { student }\end{array}$ & level CП & level CO & & $\begin{array}{c}\text { number of } \\
\text { student }\end{array}$ & level CП & level CO & \\
\hline 1 & 174 & 106 & high-low & 19 & 123 & 117 & low-high \\
\hline 2 & 160 & 115 & high-low & 20 & 180 & 140 & high-high \\
\hline 3 & 174 & 115 & low-high & 21 & 156 & 118 & high-high \\
\hline 4 & 130 & 160 & high-low & 22 & 180 & 111 & high-low \\
\hline 5 & 160 & 115 & high-low & 23 & 185 & 143 & high-high \\
\hline 6 & 176 & 107 & low-high & 24 & 180 & 118 & high-high \\
\hline 7 & 133 & 123 & high-low & 25 & 162 & 105 & high-low \\
\hline 8 & 186 & 115 & high-low & 26 & 108 & 70 & low-low \\
\hline 9 & 175 & 88 & high-low & 27 & 181 & 115 & high-low \\
\hline 10 & 185 & 84 & high-low & 28 & 132 & 120 & low-high \\
\hline 11 & 185 & 80 & low-high & 29 & 180 & 115 & high-low \\
\hline 12 & 126 & 125 & high-low & 30 & 183 & 115 & high-low \\
\hline 13 & 173 & 78 & high-low & 31 & 145 & 110 & high-low \\
\hline 14 & 180 & 80 & high-low & 32 & 150 & 112 & high-low \\
\hline 15 & 189 & 102 & high-low & 33 & 182 & 115 & high-low \\
\hline 16 & 180 & 85 & low-high & 34 & 123 & 125 & low-high \\
\hline 17 & 132 & 130 & low-low & 35 & 180 & 115 & high-low \\
\hline 18 & 116 & 93 & low-low & & & & \\
\hline
\end{tabular}


communication. And 2 participants $(6 \%$ of the total) could increase the need for communication and reduce the fear of being rejected by the group while they had opposite results in the diagnosis of a primary test.

Final testing showed that nine participants of the experiment ( $26 \%$ of total) increased their need for communication, 7 out of 35 (20\%) decreased the fear of being rejected by the group. The magnitude of the changes is $25-30 \%$.

However, it seemed interesting and important to us, how the given set of exercises, aimed at developing communicating needs could benefit studying English by the students of experimental group. The preparation period and the experiment itself took three months. The their English classes the students could show their skills of conversation and dialogue, by "playing" in the interactive mode certain situations learned in the course of the experiment. We did not expect immediate changes after the experiment for the best in the language level. However we did saw increase in motivation, which was soon followed in language knowledge results, shown by Cambridge tests. The tests were taken in the end of the second year of studying and included (like in the first year) reading, writing, listening and speaking. The maximum possible number of points was 25. 0-9 correspond to beginner; 1014 - to pre-intermediate; $15-19$ - to intermediate; 20-25 - to upper intermediate. Comparing the results of the first and second year tests is possible by the following graphs (Fig. 1-2).

As is possible to see from these graphs, there is $35-40 \%$ improvement in all four types of speech activities, and especially in listening and speaking.

\section{Conclusion}

So, our study of motivation to communicate in foreign language lessons at university was carried out in three stages. On the first stage we estimated and analyzed two motivating tendencies among the students of the

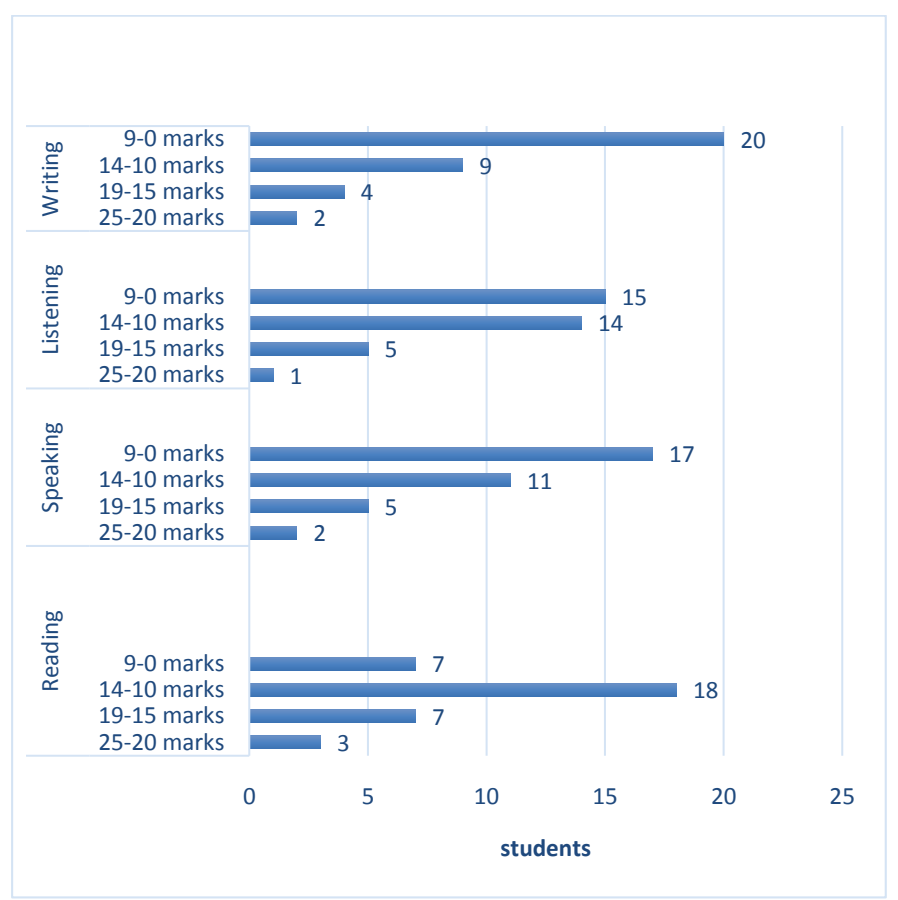

Fig. 1. Language level of students by the end of the 1-st year 


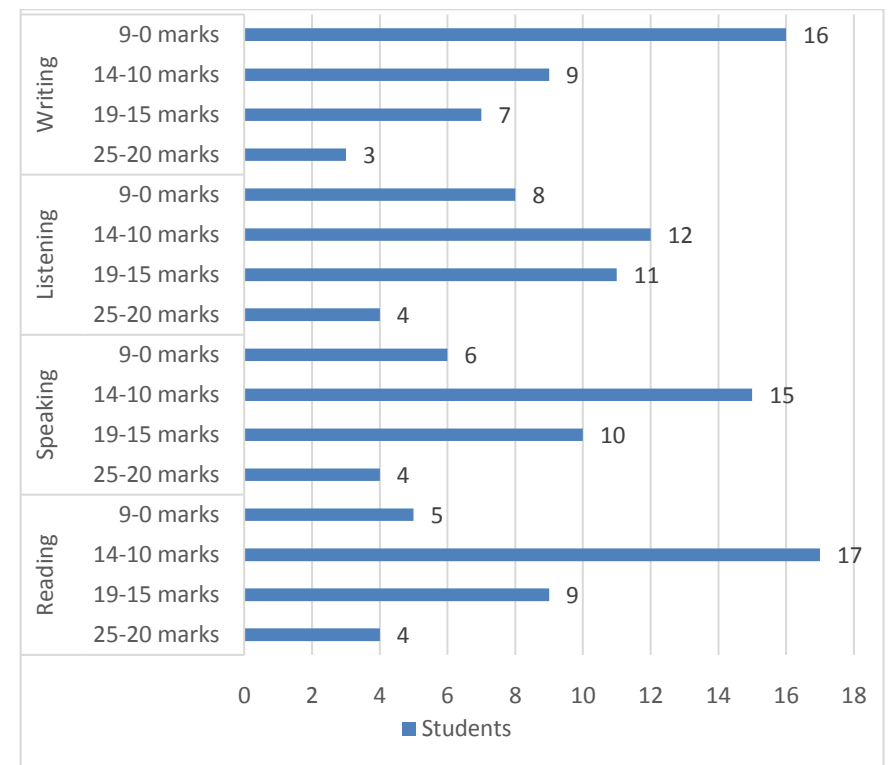

Fig. 2. Language level of students by the end of the 2-nd year

experimental group. At the second stage we used the program of: "Formation of communicating motivation in the process of studying foreign language in higher school which showed increase in communication needs among 9 of 35 tested students, 7 students reduced the fear of being rejected by the group. The magnitude of changes was $25-30 \%$. The following qualities have been formed, as a result of the experiment: they have learned to behave on the basis of mutual respect, to understand feelings, emotions, states of other people. They have learned to feel responsibility for their thoughts and act, to control their own and other people emotions in the course of intra-personal communication. In their turn, the qualities developed by the tested students have had some positive influence on their language skills.

\section{References}

Asrian, A.G. (2009). Motivaciya studentov negosudarstvennykh vuzov [Students Motivation of Commercial High Schools], In Sibirskiy pedagogicheskiy zhurnal [Siberian pedagogical journal], 13, 353-358.

Erastov, N.P. (1979). Psihologiya obshcheniya [Psychology of Communication: Manual for students-philologists]. Yaroslavl. 308 p.

Federal'nyj gosudarstvennyj obrazovatel'nyj standart vysshego professional'nogo obrazovaniyatret'ego pokoleniya (Russian Federal State Educational Standard soft he third generation (FSES 3+). Available at: http://www.edu.ru/db/mo/Data/d 14/m947.pdf (accessed 7 February 2016)

Gay, F. (2006). (Hrsg.): DISG-Persönlichkeitsprofil, GABAL-Verlag GmbH, Offenbach, 178 p.

Hekhauzen, H. (2003). Motivaciya i deyatelnost [Motivation and Activity]. St. Petersburg. 860 p.

Larina, E.A. (2011). Organizaciya motivoobrazuyushchey uchebnoy deyatelnosti studentov kak uslovie formirovaniya professionalno-eticheskoy napravlennosti $\mathrm{v}$ khode inoyazychnoy podgotovki $\mathrm{v}$ vuze [The Organization of the Motivation of Students' Teaching Activities as a Condition of Professional Ethical Orientation in the course of a Foreign Language Training in High School], In Vektor nauki Tolyattinskogo gosudarstvennogo universiteta [Scientific vector of Tolyatti State University], 4. 460-462. 
Kunitsyna, V.N., Kazarinova, N.V. (2001). Mezhlichnostnoe obshchenie [Interpersonal communication: College textbook]. St. Petersburg, 2001. 544 p.

Mitina, A.M. (2004). Zarubezhnye issledovaniya uchebnoy motivacii vzroslykh [The Foreign Investigations of Academic Adult Motivation], In Vestnik Moskovskogo universiteta [Bulletin of Moscow University]. 2, 56-65.

Sukhanova, L.A. (2010). Pedagogicheskie usloviya formirovaniya uchebnoy motivacii studentov negosudarstvennykh vuzov [Pedagogical Requirements of Learning Student Motivation of Commercial High Schools], In Gumanitariy: Aktualnye problemy gumanitarnykh i estestvennykh nauk [Scholar: Contemporary issues of liberal arts and sciences], 8, 34-42.

\title{
Из опыта формирования мотивации общения у обучающихся иностранному языку \\ в техническом вузе
}

\author{
Е.Н. Каракозова, Ю.С. Перевезенцева, \\ Д.В. Ласточкин \\ Нижегородский государственный университет \\ им. Р.Е. Алексеева \\ Россия, 603950, Нижний Новгород, ул. Минина, 24
}

\begin{abstract}
В данной статье приведено описание эксперимента, направленного на развитие мотивации иноязычного общения у студентов технического вуза. Исследование было проведено в три этаnа. Первый этап проводился с иелью диагностики состояния мотивации студентов по тесту А. Мехрабиана. Второй этап представлял собой формирующий эксперимент, проведенный на базе программ «Формирование мотивации общения в процессе обучения иностранному языку в вузе». В данные программы были включены определенные задания и упражнения, направленные на развитие коммуникативных умений слушателей (налаживание контакта, развитие уверенности в себе и самосознания). Третьим этапом стала итоговая диагностика, представлявщая собой повторное тестирование для определения уровня потребности в общении у студентов. Результаты, полученные благодаря пристальному рассмотрению динамики мотивации общения, могут позволить регулировать развитие личностных качеств студентов.
\end{abstract}

Ключевые слова: коммуникативные умения, мотивация общения, аффилиация, личностные качества студента.

Научная специальность: 13.00.00 - педагогические науки, 19.00.00-nсихологические науки. 